\section{Institutional quality and access to financial services: evidence from European transition economies}

\author{
Germana Corrado \\ Department of Management and Law, Faculty of Economics, \\ University of Rome Tor Vergata, Rome, Italy
}

The perceived quality of the institutions

Received 19 March 2019 Revised 10 August 2019 20 November 2019

\begin{abstract}
Purpose - This paper outlines an analytical framework for estimating households' access to formal credit across European transition economies shortly after the onset of the global financial crisis. This study, along with the individual-level socio-economic and demographic characteristics also considers the perceived quality of the institutions. The author wants to assess whether an adequate policy-level intervention to promote financial inclusion should account for the individuals' subjective evaluation of the political situation in their own country as well as their personal experience of corruption.

Design/methodology/approach - This paper identifies the main determinants of financial inclusion using European microdata (Life in Transition Survey II, LiTS II). In order to estimate individuals' access to formal financial markets, the author constructs a bivariate probit model to account for joint access to short-term and long-term credit products (Mohieldin and Wright, 2000).

Findings - The results show that improving people's access to financial markets across European regions requires a set of interventions at the institutional and local levels to link-up policies of financial inclusion and financial integrity.

Originality/value - The paper contributes to the existing literature by identifying a number of key causes of financial inclusion and the role of institutional (corruption crimes) factors in determining the levels of financial access in a country.
\end{abstract}

Keywords Formal credit services, Transition economies, Corruption, Bivariate probit

Paper type Research paper

\section{Introduction}

Financial exclusion is quite widespread across Europe: after the onset of the global financial crisis around a quarter of European households reported difficulties in getting a credit card, a third in getting a loan and almost a half in getting a mortgage approved, with large disparities between countries and between regions within countries [1]. It is widely recognized that those who are unable to access financial services face greater challenges in achieving social and economic integration. Access to credit is fundamental to smooth consumption plans but it is also a key instrument to access other financial services. Lack of access to or usage of credit services also impacts on achieving the minimum national standard of living which can stigmatize people. Also, "credit excluded" people who are refused access to credit by mainstream lenders are exposed to informal moneylenders who lend money at very high or extortionate rates, further exacerbating their vulnerability (Lämmermann, 2010). The recent financial and economic crisis represents an important source of concern which could worsen

(C) Germana Corrado. Published by Emerald Publishing Limited. This article is published under the Creative Commons Attribution (CCBY 4.0) licence. Anyone may reproduce, distribute, translate and create derivative works of this article (for both commercial and non-commercial purposes), subject to full attribution to the original publication and authors. The full terms of this licence may be seen at http://creativecommons.org/ licences/by/4.0/legalcode

The author wishes to thank the Editor and two anonymous reviewers. She gratefully acknowledges the "Consolidate the Foundations Grant" awarded by the University of Rome Tor Vergata (ID E82F16000450005).

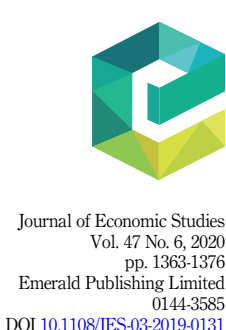

DOI 10.1108/JES-03-2019-0131 
JES

47,6

1364

the problem of financial exclusion. This stems from a tendency of the mainstream financial markets toward a sort polarization between those who are financially "hyper-included" and those who are excluded or unbanked since they have no access even to basic financial services, i.e. bank accounts (Kempson and Whyley, 1999; Claessens, 2006).

Financial exclusion has been defined in the literature as "The inability, difficulty or reluctance of particular groups to access or use mainstream financial services [2] that are appropriate to their needs and allow them to lead a normal life in the society which they belong to." (McKillop and Wilson, 2007, p. 9). The term financial exclusion was originally coined by geographers Leyshon and Thrift (1995) as resulting from limited physical (geographical) access to financial services caused by bank branch closures. Only from the 1990s afterward more attention has been devoted to financial exclusion defined as the extent to which individuals, firms and households lack access to mainstream financial products and services, including bank accounts, credit, savings and insurance (Kempson and Whyley, 1999). Several studies were recently carried out on financial exclusion by academics (Anderloni and Carluccio, 2006; Brown et al., 2011; Carbo et al., 2005; Devlin, 2005; Gloukoviezoff, 2006; Sinclair, 2001), policy makers and international institutions (European Commission, 2010; World Bank, 2012). People worldwide are encountering difficulties in accessing or using necessary financial services in the mainstream market, and reducing financial exclusion is an important and crucial dimension to be taken into account to fight poverty and social exclusion (Corrado and Corrado, 2017). Amartya Sen (2006) argued that ultimately poverty must be seen in terms of poor living standards, rather than in terms of low income. Therefore a deprived life implies the absence of opportunities, security and ability to participate in the economic and political life. Poor people have generally no access to basic financial services which, in turn, reinforces the risk of social exclusion [3] and income inequality. Modern development theories increasingly emphasize the strategic role of accessing to financial services as part of a much wider social and economic exclusion (Rajan and Zingales, 2003; Demirgüç-Kunt et al., 2007; Demirgüç-Kunt; Klapper, 2012; Allen et al., 2012; Honohan, 2008; Kendall et al., 2010).

There are four main forms of financial exclusion, each with several possible degrees of intensity: transaction banking, savings, credit and insurance. The exclusion from basic financial services is presented as the most serious form of financial exclusion, given the widespread and the vital role of these services in many transactions such as, for example, the receipt of regular payments, like salaries or pensions, the ability to cash checks, pay utilities, or pay for the goods with electronic money. Owning a bank account is now increasingly necessary to access a range of financial services and products related to the daily management of payments, savings and credit. Therefore, it is generally acknowledged that financial exclusion is a relative and multi-faceted concept with different degrees of exclusion. In this analysis, we consider two different levels of access to financial services: (1) people partially banked or underbanked who have access to basic financial services; for example, they have a bank account and an electronic payment card, such as a credit card and (2) people "fully banked" who have access to a wider range of financial services tailored to their needs, such as long-term credit in the form of collateralized loans.

The underlying assumption is that the access to transaction services (a bank account and/ or a payment card) is a key to access other financial services, in particular to long-term credit services such as mortgages. Hence, access to credit services is paramount to assess the individual-level of financial inclusion. As stressed above, the difficulty encountered by financially excluded people to have access to external lines of credit definitely has a strong impact on the level of social inclusion of individuals. In fact, the use of external credit, especially long-term credit, by affecting the habits and spending decisions and savings, is an integral part of the consumption plans of a family; therefore, it directly influences the responsiveness and protection against unexpected events. Access to credit increases also social mobility, vocational training, improvement of housing conditions and the overall quality of life that contribute positively to the self-esteem of individuals. One of the negative 
consequences of the refusal by formal financial intermediaries is the reliance on alternative sources of credit either informal (friends, relatives, associations, institutions of mutual support, etc.) or illegal (such as unlicensed moneylenders and usurers).

This study contributes to the existing literature in the following way. It outlines an analytical framework for financial inclusion using microeconomic survey data collected after the global crisis across the European transition countries. We have taken into account, along with traditional individuals' socio-economic and demographic controls, also the individual subjective perception of the quality of the political and administrative institutions using European microdata on corruption episodes (bribery). We want to assess whether an adequate policy-level response to financial exclusion across European economies should also account for the individuals' subjective evaluation of the socio-economic and political environment as well as their experience of corruption in the public sector and the incidence of other law-breaking activities. On this point, Claessens and Leaven (2003) and Demetriades and Andrianova (2004), among others, have shown that the financial system is more inclusive in countries with observance of the law fair, efficient enforcement of the rule of law especially in creditors' and debtors' rights and relationships. Rojas-Suarez and Amado (2014) find a negative relationship between weak rule of law and financial inclusion both for developing and high-income economies; as a proxy of the quality of institutions the authors use the "rule of raw" pillar of the Worldwide Governance Indicators (WGI), which measures "Agents' confidence in and commitment to abiding by the rules of society, the quality of contract enforcement, the police, the courts and the likelihood of crime and violence." (Rojas-Suarez and Amado, 2014, p. 14). In line with this more recent economic literature, our work aims at investigating whether along with socio-economic factors also the institutional environment where the financial system operates may influence financial intermediaries' provision of basic financial services to large segments of the population. Our results show that in certain European regions improving access to financial markets requires a set of interventions at the institutional and local level to prevent unlawful practices and to link-up policies of financial integrity and financial inclusion of the poorest and most vulnerable segments of the population. Our findings are in line with wellestablished literature on the causal relationship between corruption and income inequality (see, among others, Batabyal and Chowdhury, 2015; Dincer and Gunalp, 2011; Apergis et al., 2010; Mo, 2009; You and Khagram, 2005; Gupta et al., 2002; Gyimah-Brempong, 2002; Easterly and Fischer, 2001) showing that corruption affects more individuals who belong to low-income groups. Moreover, corruption by rising the wealth gap between the rich and the poor makes the latter group more vulnerable to financial exclusion which, in turn, contributes to further increasing income inequality. When credit is inclusive it creates economic opportunity to those who may not have the means today, allowing them to access the resources necessary for survival and to pursue opportunities for higher earnings.

The paper is structured as follows. Section 2 presents data and methodology. Section 3 introduces the analytical framework. Section 4 presents and discusses the results. Section 5 concludes.

\section{Data}

We use a cross-country dataset built surveying people across European transition economies and five Western "comparator" countries. The second round of the Life in Transition Survey II (LiTS II) conducted jointly by the European Bank for Reconstruction and Development (EBRD) and the World Bank in 2010; it surveyed almost 39,000 households in the transition region which covers 35 countries in Central-Eastern Europe and the Baltic region, South-Eastern Europe plus Turkey, the Commonwealth of Independent States and Mongolia. The coverage has been expanded allowing to benchmark the transition region against some advanced market economies represented by five Western European neighboring countries, defined as the "comparators" and represented by France, Germany, Italy, Sweden and the UK. LiTS II also
The perceived quality of the institutions

1365 
JES

47,6

1366

Figure 1.

Credit by Macro-

Regions (Author's

calculations using data

from LiTS, 2010).

"Western Europe" comprises: France, Germany, Italy, Sweden and the UK "Central-Eastern and Baltic States" includes Czech Republic, Estonia, Hungary, Latvia, Lithuania, Poland, Slovak Republic, Slovenia. "South-Eastern Europe" comprises Albania, Bosnia and Herzegovina, Bulgaria, Croatia, Kosovo, Macedonia, Montenegro, Romania, Serbia plus Turkey allows to detect individuals' assessments about their well-being, their attitudes to the role of government, democracy and their perceptions and experience of corruption. We consider the following eighteen European transition economies: Czech Republic, Estonia, Hungary, Latvia, Lithuania, Poland, Slovak Republic, Slovenia, Albania, Bosnia and Herzegovina, Bulgaria, Croatia, Kosovo, Macedonia, Montenegro, Romania, Serbia and Turkey.

The first part of the questionnaire concerns the composition and type of family, housing conditions and spending. The second part of the survey provides a range of information on individual socio-economic and demographic characteristics, such as the respondent's current and past professional activity, level of education, religion, household income and composition and nationality of respondents.

Finally, there are two new sections in the LiTS II questionnaire. One on the key attitudes and values where respondents are asked to answer on their overall sense of well-being and optimism, their views on markets, democracy and the role of the government and their attitudes toward particular population groups. The other section collects respondents' views on trust-social and institutional-and corruption both low-level administrative corruption and high-level corruption.

An approach to measuring [4] access and usage of financial services is to count the number of users of basic financial services [5]. Proxy for access to financial services that is more readily amenable to measurement is the use of a wider range of financial services and products than simply access to an entry-level bank account (Honohan, 2008) [6]. We employ two indicators of households' usage of financial services. The first is the dummy variable credit card that indicates whether any member of the household holds a credit card which allows him/her to access a short-term loan [7]. The second is the dummy variable mortgage that indicates whether any member of the household has asked and obtained a secured (collateralized) long-term loan. Figure 1 shows the average access and usage of the above credit facilities across Europe: households in transition economies are much less likely to have a credit card or other forms of borrowing such as mortgages than their counterparts in Western Europe.

Among the explanatory variables, we use socio-economic and demographic controls. The variable household's income has been built by summing total household's expenses over the year (both in durable and nondurable goods) [8] plus savings all expressed in the same

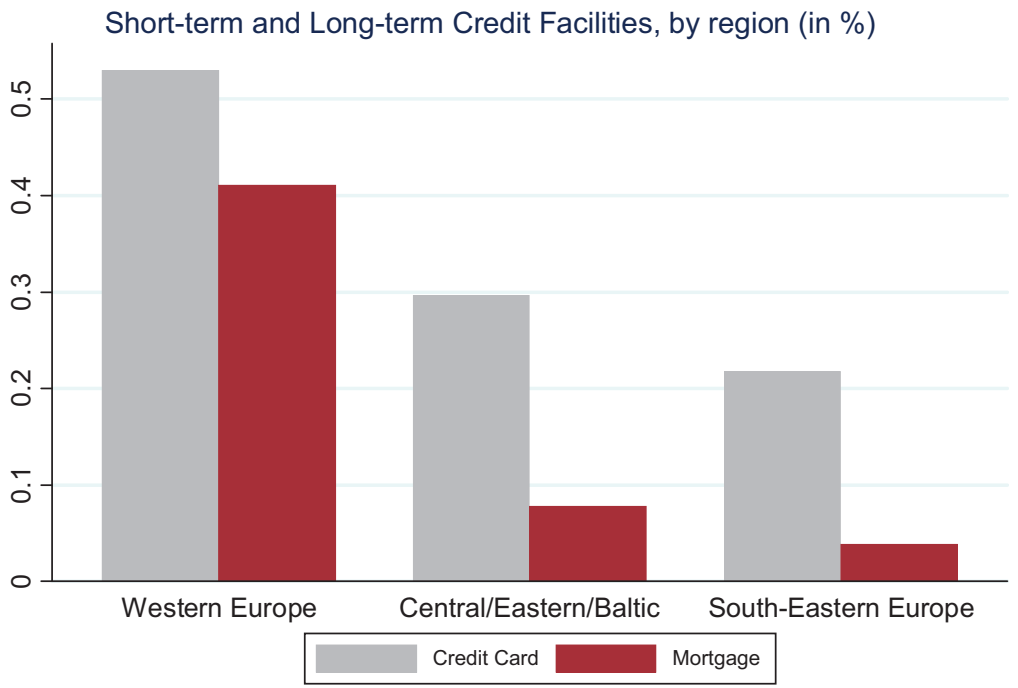

Source(s): LiTS, 2010 
currency, US dollars. We use some dummy variables to capture the main source of household income: wage or self-employment income, state benefits, pensions. The other individual characteristics are gender, age, marital status, number of children in the household, education attainment, language and religion; in particular, we consider Muslim households that may choose, for religious reasons, not to deal with non-Islamic financial institutions which offer financial products that are not structured in compliance with the principles of Islamic law (Shariah). We also include the household's place of residence - whether the household is located in an urban, metropolitan or rural area - and their subjective assessments of the quality of the institutions - whether they reported experience of corruption crimes when dealing with public services [9] - and of the political situation of the country. In particular, we are interested in our analysis in controlling for corruption since it distorts political and economic systems by allowing those who can afford to bribe state officials to "bypass" legal and regulatory obligations. We insert as a control variable the individuals' personal experience of corruption. Figure 2 shows the distribution of this variable across the European macro-regions including the Western European countries, while Figure 3 shows for those who report paying bribes to public officials the reason for doing this. Table 1 lists the variables used in the econometric analysis and Table 2 reports the summary statistics.

\section{The econometric model}

Respondents' access and usage of financial services are assumed to be influenced by the individual and household characteristics as well as by institutional factors such as the experience of corruption crimes (i.e. bribery). The latent variable $y_{i}^{*}$ represents the $i$-th household's usage of financial services. This depends on a vector of explanatory variables, $\boldsymbol{x}_{\mathrm{i}}$, which includes individual and household demographic characteristics as well as institutional and socio-economic factors. This leads to a response model which can be presented as:

$$
y_{i}^{*}=\boldsymbol{x}_{\mathrm{i}} \boldsymbol{\beta}+\varepsilon_{i}
$$

The household's usage of financial services $y_{i}^{*}$ like short-term credit (credit cards) or longterm credit (mortgages) is assumed to be dependent on the bank's credit risk assessment but also on the individuals' assessment of the marginal cost and benefits associated with the usage and non-usage of these facilities. Based on both these assessments the respondent may

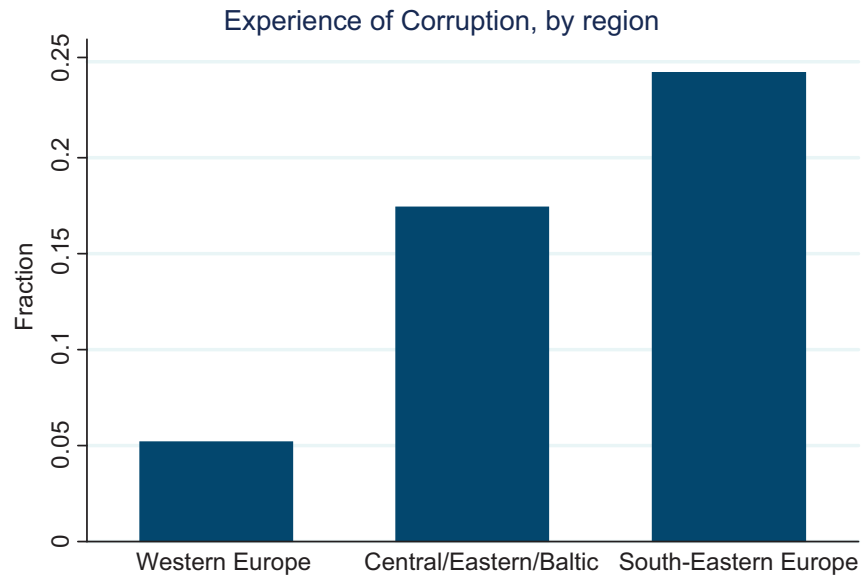

Source(s): LiTS, 2010
The perceived quality of the institutions

1367

Figure 2.

Corruption by MacroRegion (Author's calculations using data from LiTS, 2010).

"Western Europe" comprises: France, Germany, Italy,

Sweden and the UK

"Central-Eastern and

Baltic States” includes Czech Republic,

Estonia, Hungary,

Latvia, Lithuania, Poland, Slovak

Republic, Slovenia. "South-Eastern

Europe" comprises

Albania, Bosnia and Herzegovina, Bulgaria, Croatia, Kosovo, Macedonia, Montenegro, Romania, Serbia plus Turkey 
JES

47,6

\section{8}

or may not access and use credit services. In reality, we do not observe this marginal costs and benefits neither the bank's credit risk assessment, based on the individual characteristics, hence the dependent variable $y_{i}^{*}$ in equation (1) is unobservable. One can only observe whether the respondent uses credit or not through the survey questionnaire. Hence, we define another variable $y_{i}$ that leads to a binary outcome for the dependent variable such that:

$$
\begin{aligned}
& y_{i}=0 \text { if the respondent uses a credit service } \\
& y_{i}=1 \text { if the respondent does not use a credit service }
\end{aligned}
$$

In order to assess more formally respondents' level of financial inclusion we follow Mohieldin and Wright (2000) and Corrado and Corrado (2015) by using a bivariate probit model, with the following econometric specifications:

$$
\begin{gathered}
y_{1 i}^{*}=\boldsymbol{x}_{1 \mathrm{i}} \boldsymbol{\beta}_{1}+\varepsilon_{1 i} \quad y_{1 i}=\left\{\begin{array}{l}
1 \text { if } y_{1 i}^{*}>0 \\
0 \text { if } y_{1 i}^{*} \leq 0
\end{array}\right. \\
y_{2 i}^{*}=\boldsymbol{x}_{2 \mathrm{i}} \boldsymbol{\beta}_{2}+\varepsilon_{2 i} \quad y_{2 i}=\left\{\begin{array}{l}
1 \text { if } y_{2 i}^{*}>0 \\
0 \text { if } y_{2 i}^{*} \leq 0
\end{array}\right. \\
E\left(\varepsilon_{1 i}\right)=E\left(\varepsilon_{2 i}\right)=0 \operatorname{Var}\left(\varepsilon_{1 i}\right)=\operatorname{Var}\left(\varepsilon_{2 i}\right)=1 \operatorname{Cov}\left(\varepsilon_{1 i}, \varepsilon_{2 i}\right)=\rho i=1,2, \ldots, n
\end{gathered}
$$

where $y_{1 i}^{*}$ is the latent variable, that is the latent utility from using short-term credit (holding a credit card); $y_{1 i}$ is the observed response for those who use a credit card and we can define as partially banked. While $y_{2 i}^{*}$ is the utility that individuals can derive from getting a long-term credit (a mortgage) and $y_{2 i}$ is the observed response for those who have long-term credit and are defined as fully banked; $\boldsymbol{x}_{1 \mathrm{i}}$ and $\boldsymbol{x}_{2 \mathrm{i}}$ are $(1 \times k)$ vectors of explanatory variables with $\boldsymbol{\beta}_{1}$ and $\boldsymbol{\beta}_{2}$ being their associated $(k \times 1)$ parameter vectors; $\varepsilon_{1 i}$ and $\varepsilon_{2 i}$ are random error terms that are jointly bivariate normal with correlation equal to $\rho$.

The respondent has a propensity (latent utility) to use short-term credit $\left(y_{1 i}^{*}\right)$ not directly observable. When the latent utility becomes positive $\left(y_{1 i}^{*}>0\right)$ then the use of transaction services (credit cards) is observed $\left(y_{1 i}=1\right)$. This is identical to the standard latent variable

Figure 3.

Reasons for Bribing across Macro-Regions (Author's calculations using data from LiTS, 2010). "Western Europe" comprises: France, Germany, Italy, Sweden and the UK "Central-Eastern and Baltic States" includes Czech Republic, Estonia, Hungary, Latvia, Lithuania, Poland, Slovak Republic, Slovenia. "South-Eastern Europe" comprises Albania, Bosnia and Herzegovina, Bulgaria, Croatia, Kosovo, Macedonia, Montenegro, Romania, Serbia plus Turkey

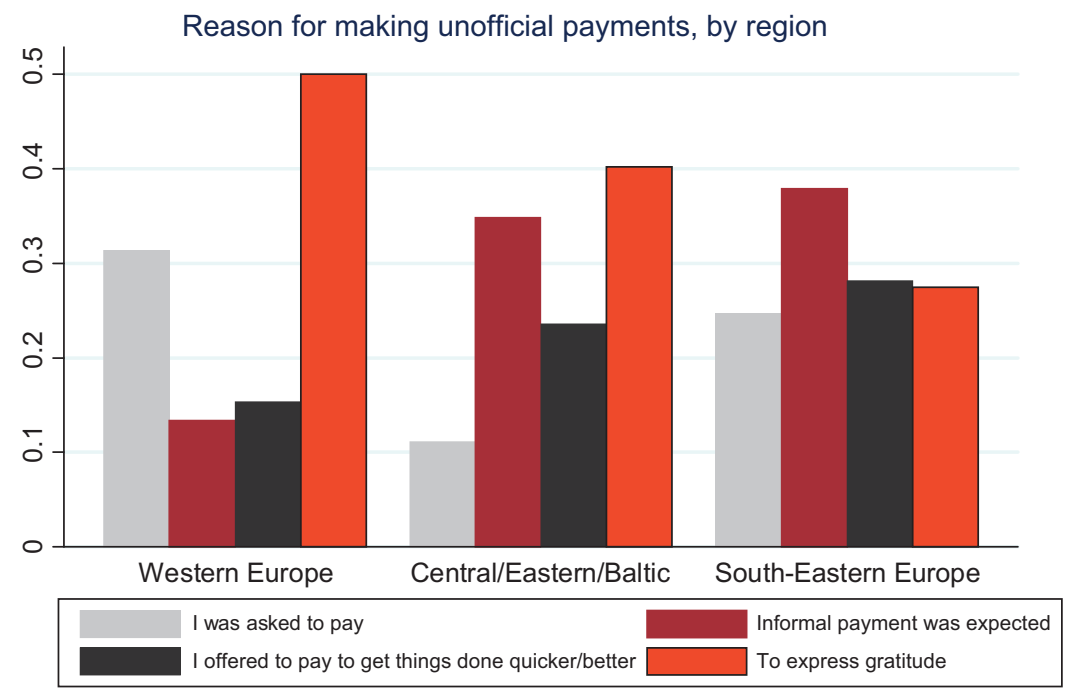

Source(s): LiTS, 2010 


\begin{tabular}{|c|c|c|}
\hline Variables & Categories & Description \\
\hline Credit card & Binary & $\begin{array}{l}\text { "Do you or anyone in your household own a credit card?" } 1=\text { Yes and } \\
0=\text { No }\end{array}$ \\
\hline Mortgage & Binary & "Do you currently have a mortgage?" $1=$ Yes and $0=$ No \\
\hline \multicolumn{3}{|l|}{ Region dummies } \\
\hline EU member & Binary & $\begin{array}{l}\text { Dummies for European Union countries: "Bulgaria”, "Croatia”, } \\
\text { "Czech", "Estonia”, "Hungary", "Latvia”, "Lithuania”, } \\
\text { "Poland", "Romania", "Slovakia", "Slovenia” }\end{array}$ \\
\hline Macro-region & Binary & $\begin{array}{l}\text { Dummies for macro-regions: "Central-Eastern Europe and the Baltic } \\
\text { States" (CEB) which includes Czech Republic, Estonia, } \\
\text { Hungary, Latvia, Lithuania, Poland, Slovak Republic, Slovenia; and } \\
\text { South-Eastern Europe (SEE) which includes Albania, } \\
\text { Bosnia and Herzegovina, Bulgaria, Croatia, Kosovo, Macedonia, } \\
\text { Montenegro, Romania, Serbia plus Turkey }\end{array}$ \\
\hline
\end{tabular}

Socio-economic and demographic characteristics

\begin{tabular}{|c|c|c|}
\hline Gender & Binary & Dummy for $1=$ Female; $0=$ Male \\
\hline Age & Binary & $\begin{array}{l}\text { Dummies for respondent's age: "Young" if he/she is } 18-34 \text { years of age; } \\
\text { "Middle-aged" if he/she is } 35-54 \text { years of age; } \\
\text { "Older" if he/she is } 55 \text { years of age or older }\end{array}$ \\
\hline Marital status & Binary & $\begin{array}{l}\text { Dummy variables for: "Single”; "Widowed"; "Separated/Divorced”. } \\
\text { Ref. Cat.: "Married" }\end{array}$ \\
\hline Educational level & Binary & $\begin{array}{l}\text { Dummy if the respondent's highest level of education is a Bachelor's } \\
\text { degree, a Master's degree or a Ph.D }\end{array}$ \\
\hline Children & Continuous & "How many children are living in the household?" \\
\hline Income & Continuous & Household's income expressed in USD per year (in Logs) \\
\hline Muslim & Binary & Dummy if respondent is Muslim \\
\hline Official language & Binary & $\begin{array}{l}\text { Dummy if respondent speaks any of the official languages of the } \\
\text { country }\end{array}$ \\
\hline Residence & Binary & $\begin{array}{l}\text { Dummies for "Urban/Metropolitan area", if the respondent lives in a } \\
\text { metropolitan or in an urban area; Ref. Cat.: "Rural Area" }\end{array}$ \\
\hline
\end{tabular}

Institutional factors Experience of Binary corruption

Dummy if "the respondent or any of the member of the household has made an unofficial payment or gift in the last 12 months when using the following public services: interacting with police; interacting with the judiciary; receiving public education receiving medical treatment in the public healthcare system; requesting unemployment or social security benefits. $1=$ Yes $0=$ No Subjective political Binary Dummy variable for: "The political situation in our country is better Situation today than around 4 years ago" $1=$ Yes and $0=$ No

Table 1 .

Note(s): Individuals are sampled using the Primary Sample Unit (PSU) area-code. Source of data: LiTS II 2010

Variables description

approach of the probit model. However, in the bivariate probit model framework, the respondent is assumed to have also a propensity (latent utility) to use long-term credit facilities $\left(y_{1 i}^{*}\right)$ which again is observed $\left(y_{2 i}=1\right)$ if the latent utility is positive $\left(y_{2 i}^{*}>0\right)$. It is possible that the probability to use both financial services-short and long-term credit-may not be independent; therefore, we allow the random error of the two equations -one for the partially banked households and the other for the fully banked households- to be correlated, with correlation coefficient $\rho$.

\section{Households' access to long-term credit}

We analyze the determinants of households' access to secured long-term and unsecured short-term loans [10]. Since our results show that corruption is not affecting access to short- 


\begin{tabular}{|c|c|c|c|c|c|c|}
\hline \multirow[b]{2}{*}{$\begin{array}{l}\text { JES } \\
47,6\end{array}$} & \\
\hline & Variable & Observations & $\begin{array}{c}\text { Means (\% if } \\
\text { counts) }\end{array}$ & Std. Dev & Min & Max \\
\hline \multirow[b]{5}{*}{1370} & Credit card & 19,638 & 0.289 & 0.453 & 0 & 1 \\
\hline & Mortgage & 17,348 & 0.062 & 0.242 & 0 & 1 \\
\hline & Female & 19,621 & 0.588 & 0.492 & 0 & 1 \\
\hline & Middle-aged & 19,642 & 0.350 & 0.477 & 0 & 1 \\
\hline & Older & 19,642 & 0.345 & 0.475 & 0 & 1 \\
\hline \multirow[b]{12}{*}{$\begin{array}{l}\text { Table } 2 \text {. } \\
\text { Summary statistics }\end{array}$} & Single & 19,527 & 0.583 & 0.492 & 0 & 1 \\
\hline & Separated/divorced & 19,527 & 0.083 & 0.276 & 0 & 1 \\
\hline & Widowed & 19,527 & 0.122 & 0.327 & 0 & 1 \\
\hline & Children & 19,642 & 0.530 & 0.909 & 0 & 7 \\
\hline & Higher education & 19,642 & 0.155 & 0.361 & 0 & 1 \\
\hline & Income (in Logs) & 17,816 & 8.716 & 0.802 & 1.571 & 14.307 \\
\hline & Muslim & 19.177 & 0.209 & 0.406 & 0 & 1 \\
\hline & Official language & 19,642 & 0.924 & 0.264 & 0 & 1 \\
\hline & Urban/metropolitan area & 19,642 & 0.611 & 0.487 & 0 & 1 \\
\hline & Experience of corruption & 14,878 & 0.201 & 0.401 & 0 & 1 \\
\hline & Subjective evaluation of political & 18,796 & 2.375 & 1.096 & 1 & 5 \\
\hline & $\begin{array}{l}\text { situation } \\
\text { EU member }\end{array}$ & 19,642 & 0.600 & 0.489 & 0 & 1 \\
\hline
\end{tabular}

term credit, we focus on the impact of selected socio-demographic and institutional variables on access to long-term credit (i.e. mortgages). Specifically, we are interested in investigating the effect of corruption on households' access to finance via the corruption-asset income inequality link; the penultimate column of Table 3 reports the marginal effect at the means (MEMs) of each covariate on access and usage of long-term credit.

The $\chi^{2}(1)$ Wald test on the statistical significance of the correlated effects $\left(H_{0}: \rho=0\right.$ vs $\left.H_{1}: \rho \neq 0\right)$ suggests that both the access to some basic financial services used for transactions/payments and to long-term collateralized credit display some correlation that cannot be entirely accounted for by the inclusion of our controls. From a purely statistical viewpoint, a positive and statistically significant $\widehat{\rho}$ indicates a positive and interactive correlation between the two dependent variables, suggesting that it is potentially harmful to explore them separately. An alternative way to interpret a statistically significant correlation between the error terms is to think about the impact of other determinants of access to shortterm and long-term credit that are not fully accounted for by observable effects in the model, although they also influence the dependent variables. Therefore, ruling out the assumption of correlated disturbances may potentially bias the estimates (Corrado and Corrado, 2015).

In Table 3 we report the estimates for the European transition regions that embrace both South-Eastern Europe (SEE) comprising Albania, Bosnia and Herzegovina, Bulgaria, Croatia, Kosovo, Macedonia, Montenegro, Romania, Serbia plus Turkey and Central-Eastern Europe and Baltic States (CEB), where the latter macro-region includes Czech Republic, Estonia, Hungary, Latvia, Lithuania, Poland, Slovak Republic, Slovenia.

Among the explanatory variables, we include (1) "Socio-Economic and Demographic Characteristics" and (2) "Institutional Factors". The first category comprises individual-level characteristics such as age, gender, educational attainment [11], income, number of children, marital status, language, religion and place of residence. While in the second category we consider other relevant variables such as the subjective evaluation of the current political situation of the country where households live. We also consider among the controls the individuals' experience of corruption: respondents are asked whether they or any member of the household have made an unofficial payment or gift over the last 12 months when interacting with public officers or bureaucrats [12]. 


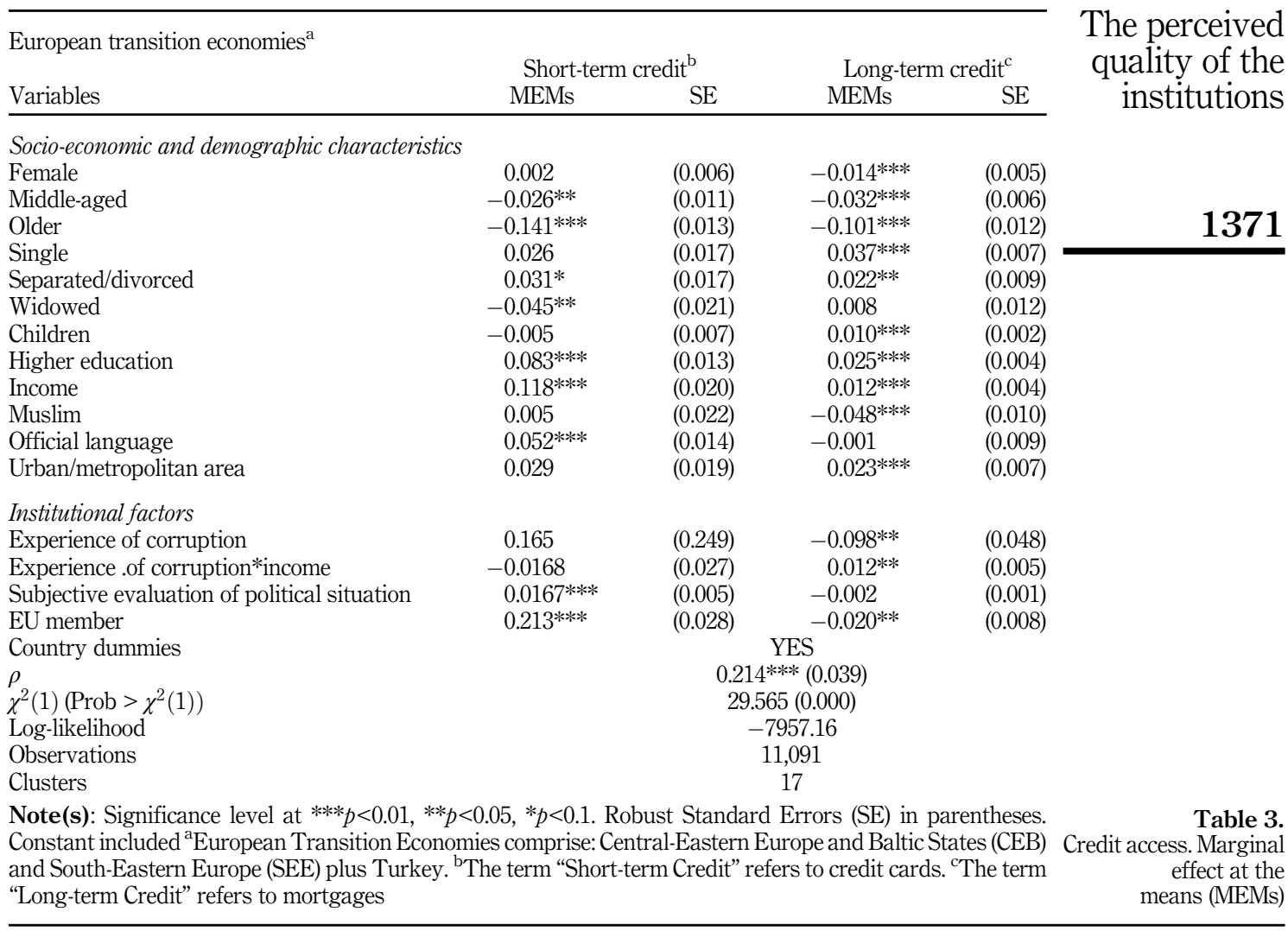

\subsection{Socio-economic and demographic characteristics}

Results confirm that age is one of the key factors affecting the respondent's likelihood of being approved for a mortgage. Table 3, penultimate column, shows that the two age groups "middle-aged" and "older" have a lower probability to access long-term credit than their younger counterparts. In particular, among those aged 35-54 and those aged 55 or older the probability of getting a mortgage drops respectively by 3.2 and $10.1 \%$ (in percentage points). This result can be explained by several reasons: on the one hand, older people have a lower propensity to demand and use credit, on the other hand, they are also more likely to be excluded from long-term finance by the intermediaries for eligibility reasons. Financial intermediaries across European countries impose strict age requirements [13] to the mortgagees, which became more stringent after the wake of the global financial crisis.

Unmarried people are more likely to access credit services; single and separated/divorced individuals are respectively 3.7 and $2.2 \%$ more likely to get a mortgage compared to their married counterparts. Living in a household with children increases by $1 \%$ the likelihood to access long-term finance: this may be explained by the parents' primary need to live in a suitable family home where growing their children which leads to a higher demand for mortgages: Moreover, some mortgage lenders often include child benefit payments when assessing the applicant's finances, which could help parents on lower incomes boost both their chances to get a mortgage and the amount they can borrow. 
JES

47,6

Education exhibits a positive relationship with the access to and usage of credit services. In particular, the probability of obtaining a mortgage increases by $2.5 \%$ for borrowers with a higher education attainment. Also, income has a positive impact on access to credit services; the likelihood of access long-term finance increases by $1.2 \%$ for higher-income households. These findings, therefore, confirm that higher income and higher education are positively associated with greater financial inclusion, so poor, low-income and illiterate individuals do not benefit from financial inclusion, and this exposes them to a serious threat since they cannot handle, for example, income shocks over unforeseen emergencies such as illness or a job loss.

The geographical residence also affects the probability of using and accessing formal credit services. People who reside in a metropolitan or urban area are $2.3 \%$ more likely to get a mortgage than people who live in a rural area. This result suggests that rural populations are more likely to remain excluded from the formal financial market; in the transition economies there is a clear urban-rural divide in the access to long-term credit which may widen the citycountry income inequality gap. Religion also matters: being a Muslim reduces the probability of accessing long-term credit by $4.8 \%$. This result might be explained by the underdevelopment of Islamic finance practices across Europe where Islamic banking is still at a fairly embryonic stage, and this makes Muslims more likely to be financially excluded.

\subsection{Institutional factors}

We find a quite interesting result on the impact of experienced corruption (bribes) on the access to secured credit across European regions when we control for the income level of the respondent. Corruption in transition countries has a negative and statistically significant impact on household access to credit; the probability of getting long-term credit from financial intermediaries drops by around $9.8 \%$ for higher levels of experience of corruption, as Table 3 shows. These findings might be explained in the light of the recent literature on corruption where it is recognized that there are important theoretical links between corruption and the functioning of the economic, political as well as financial institutions (Arestis et al., 2001; Claessens and Leaven, 2003; Demetriades and Andrianova, 2004; Blackburn et al., 2010; Asongu, 2014). Corruption and financial intermediation are related in several ways: a stable and well-functioning financial system can exist only if laws and regulations concerning their activities exist and if these laws are enforced. Also, corruption seems to widen the gap among the poor and the rich in terms of access to formal financial services, especially across European transition regions; this is confirmed by the sign of the interaction term Experience of Corruption *Income (see Table 3, penultimate column). It is not surprising that in the European transition economies where corruption crimes are widespread the richest people might easily circumvent regulations in the financial sector as they have more resources (income) to pay bribes to get access to formal credit facilities. Moreover, the rich can refuse to pay a bribe when they are asked because they have more wealth to pledge as collateral when they apply for large long-term loans. Our results reveal that when the quality of the institutions is low, corruption practices may hinder the wellfunctioning of the financial sector which becomes much less inclusive and more unequal since for low-income people the likelihood of being financially included decreases. This finding is in line with that strand of literature which proves empirically the existence of a link between corruption and income inequality, as we refer to earlier in this study [14]. Specifically, in our analysis this relationship is mainly driven by financial factors: since the poor are less protected by asset income when their real wages fall (Easterly and Fischer, 2001) corruption may increase income inequality; because the poor lack of resources, they cannot refuse to pay the bribes when they are asked to get access to financial services. Corruption not only directly reduces the access to credit of the poor when they cannot afford to pay bribes, but corruption also exacerbates financial exclusion indirectly since it reduces the propensity of the poor to 
apply for credit due to the additional costs of the extortion fees (i.e. illegal payments) [15]. Therefore, the vulnerability of low-income individuals to financial exclusion might increase according to a bidirectional causal relationship corruption-inequality-financial exclusioninequality-corruption, similarly to the studies of Apergis et al. (2010) and Dincer and Gunalp (2011).

\section{Conclusions}

Financial exclusion has been defined as the inability, difficulty or reluctance of individuals to access necessary financial services in an appropriate form (Sinclair, 2001; McKillop and Wilson, 2007). It can originate either from problems with individuals' access to financial services (i.e. involuntary exclusion) or from self-exclusion from formal financial markets in response to negative individual experiences or perceptions of the institutional and political environment. We performed our analysis using the EBRD and World Bank first comprehensive survey LiTS II carried out in 2010 across households living in the European transition economies. In line with more recent research, we detect among the main factors affecting access and usage of credit facilities (mortgages), households' socio-economic and demographic characteristics such as income, education, marital status, age and area of residence. However, we also find that other institutional factors seem to be relevant for enhancing financial inclusion. For example, experienced corruption might affect the access to and usage of formal financial services. Not surprisingly, in transition and emerging economies unofficial payments are often made by people to access public services and/or improve the quality of service received. In line with wellestablished literature on the relationship between corruption and income inequality, our analysis shows that in the macro-region comprising the European transition countries with lower quality of the institutions (i.e. high corruption) the likelihood for the low-income individuals to access secured credit services in the formal financial markets decreases, widening the income gap between the rich and the poor. Unlawful and corrupt practices, such as bribery, might overcome legal and administrative barriers to access formal financial services, so those, typically the poorest people, who cannot afford to pay bribes remain excluded from the formal financial markets. Our results suggest that in some European regions improving access to financial services requires a set of policy interventions at the institutional level to link-up policies of financial inclusion and financial integrity: facilitating people's access to finance through good banking practices.

\section{Notes}

1. European Commission (2010).

2. The World Bank (2012) identifies four key areas of financial exclusion: transaction banking, savings, credit and insurance.

3. Financial exclusion is strictly related to social exclusion as a cause and a consequence, although difficulties of access may not always lead to social exclusion. While social exclusion almost automatically leads to financial exclusion, the latter can be seen as a process that may increase the risk to face social exclusion (Anderloni et al., 2008).

4. It is easy to measure the usage of financial services, but usage does not imply access (Demirgüç-Kunt et al., 2007). In fact, while usage reflects both demand and supply of services, it cannot express voluntary exclusion (where services are offered but not taken up) and involuntary exclusion (where services are not offered). Ideally, the measurement of access, rather than use, should take account of both current use and voluntary exclusion. But other authors have argued that this distinction is too minimal so that one can simply focus on measuring usage of financial services (see Honohan, 2008).

5. From the data we cannot identify whether the household is excluded from the market involuntary or voluntarily, that is whether the household needs financing but he/she is rejected by the bank or
The perceived quality of the institutions 
JES

47,6

whether the household does not borrow from a financial institution because he/she does not need this form of credit by choice.

6. The use of a bank account is often seen as the primary proxy for access to financial services.

7. The survey asks to respondents whether they own a credit card, so in this sense the variable "credit card" does not necessarily indicate usage of a bank credit card. In fact, in several European countries, there are a large number of issuers who are not banks, such as specialist credit card companies plus retailers and other providers. However, this is not relevant for our analysis since we are assessing the access and usage of financial services provided from formal financial intermediaries.

8. The main items included among the expenses are: (1) Food, beverages and tobacco, (2) Utilities (electricity, water, gas, heating, landline phone service) (3) Transportation, (4) Education (including tuition, books and other kindergarten expenses) (5) Health, (6) Clothing and footwear, (7) durable goods (e.g. furniture, appliances, TV, car, home etc.)

9. LiTS II asks to the respondent the following question "Did you or any member of your household make an unofficial payment or gift when using these services over the past 12 months?: (1) Interact with the road police; (2) Request of official documents (e.g. passport, visa, birth or marriage certificate, land register, etc.) from authorities; (3) Going to courts for a civil matter; (4) Receive public education; (5) Receive medical treatment in the public healthcare system; (6) Request unemployment benefits; (7) Request other social security benefits. (Question Q6.04).

10. Our analysis can identify households who access and use financial services; however, survey microdata do not allow us to identify whether a household is excluded from the formal financial market "voluntarily" or "involuntarily". This is a limitation of the study.

11. The dummy variable "Higher Education" comprises a Bachelor's degree, a Master's degree or a Ph.D.

12. As specified in the "Data" Section, the eight public services covered by the survey are: interacting with road police; requesting official documents; going to the courts for a civil matter; receiving primary or secondary public education; receiving public vocational education; receiving treatment in the public health system; requesting unemployment benefits; requesting other social security benefits.

13. For example, in many European countries you need to be at least 18 years old to apply for a mortgage and the mortgage term must end before you are 75 years old.

14. See, among others, Dincer and Gunalp (2011), Apergis et al. (2010), Batabyal and Chowdhury (2015), Nissan and Naghshpour (2013), Mo (2009), You and Khagram (2005), Gupta et al. (2002), GyimahBrempong (2002), Easterly and Fischer (2001).

15. As reported by Apergis et al. (2010) "The burden of corruption falls disproportionately on lowincome individuals who pay a larger proportion of their incomes in the form of bribes than highincome individuals." (p. 126).

\section{References}

Allen, F., Demirgüc-Kunt, A., Klapper, L. and Martinez Peria, M.S. (2012), "The foundations of financial inclusion: understanding ownership and use of formal accounts", World Bank Policy Research Working Paper, WPS 6290, World Bank Group, Washington, DC.

Anderloni, L. and Carluccio, E. (2006), "Access to bank accounts and payment services", in Anderloni, L., Carluccio and Braga, M. (Eds), New Frontiers in Banking Services: Emerging Needs and Tailored Products for Untapped Markets, Springer Verlag, Berlin.

Anderloni, L., Bayot, B., Bledowski, P., Iwanicz-Drozdowska, M. and Kempson, E. (2008), Services Provision and Prevention of Financial Exclusion. Report Prepared for the Directorate-General for Employment, Social Affairs and Equal Opportunities, European Commission, Brussels. 
Apergis, N., Dincer, O. and Payne, J. (2010), "The relationship between corruption and income inequality in US states: evidence from a panel cointegration and error correction model", Public Choice, Vol. 145, pp. 125-135.

Arestis, P., Demetriades, P.O. and Luintel, K.B. (2001), "Financial development and economic growth: the role of stock markets", Journal of Credit and Banking, Vol. 33, pp. 16-41.

Asongu, S. (2014), "Globalization (fighting), corruption and development: how are these phenomena linearly and nonlinearly related in wealth effects?", Journal of Economic Studies, Vol. 41 No. 3, pp. 346-369.

Batabyal, S. and Chowdhury, A. (2015), "Curbing Corruption, financial development and income inequality”, Progress in Development Studies, Vol. 15 No. 1, pp. 49-72.

Blackburn, K., Bose, N. and Emranul Haque, M. (2010), "Endogenous corruption in economic development”, Journal of Economic Studies, Vol. 37 No. 1, pp. 4-25.

Brown, M., Ongena, S., Popov, A. and Yesin, P. (2011), "Who needs credit and who gets credit in Eastern Europe?”, Economic Policy, Vol. 26 No. 65, pp. 93-130.

Carbo, S., Gardner, E. and Molyneux, P. (2005), Financial Exclusion, Palgrave Macmillan, Basingstoke.

Claessens, S. and Leaven, L. (2003), "Financial development, property rights, and growth", The Journal of Finance, Vol. 58, pp. 2401-2436.

Claessens, S. (2006), "Access to financial services: a review of the issues and public policy objectives", The World Bank Research Observer, Vol. 21 No. 2, pp. 207-240.

Corrado, G. and Corrado, L. (2015), "The Geography of financial inclusion across Europe during the global crisis", Journal of Economic Geography, Vol. 15 No. 5, pp. 1055-1083.

Corrado, G. and Corrado, L. (2017), "Inclusive finance for inclusive growth and development", Current Opinion in Environmental Sustainability, Vol. 24, pp. 19-23.

Demetriades, P. and Andrianova, S. (2004). Finance and growth: what we know and what we need to know, in Goodhart, C. (Ed.), Financial Development and Economic Growth: Explaining The Links, 38-65, Palgrave Macmillan, Basingstoke and New York.

Demirgüç-Kunt, A. and Klapper (2012), "Measuring financial inclusion: the global findex database", World Bank Policy Research Working Paper, WPS 6025, World Bank Group, Washington, DC.

Demirgüç-Kunt, A., Beck, T. and Honohan, P. (2007), Finance for All? Policies and Pitfalls in Expanding Access, World Bank Policy Research Report, World Bank Group, Washington, DC.

Devlin, J.F. (2005), “A detailed study of financial exclusion in the United Kingdom”, Journal of Consumer Policy, Vol. 28, pp. 75-108.

Dincer, O.C. and Gunalp, B. (2011), "Corruption, income inequality and poverty in the United States", Contemporary Economic Policy, Vol. 30 No. 2, pp. 283-292.

Easterly, W. and Fischer, S. (2001), "Inflation and the poor", Journal of Money, Credit, and Banking, Vol. 33 No. 2, pp. 160-178.

European Commission (2010), Financial Exclusion in the EU. New Evidence from the EU-SILC Special Module), in Fondeville, N., Ózdemir, E. and Ward, T. (Eds), Research Note 3/2010, The Directorate-General for Employment, Social Affairs and Equal Opportunities, Brussels.

Gloukoviezoff, G. (2006), "From financial exclusion to overindebtedness: the paradox of difficulties for people on low income?", in Anderloni, L., Carluccio and Braga, M. (Eds), New Frontiers in Banking Services. Emerging Needs and Tailored Products for Untapped Markets, 213-245, Springer Verlag, Berlin.

Gupta, S., Davoodi, H. and Alonso-Terme, R. (2002), "Does corruption affect inequality and poverty?", Economics of Governance, Vol. 2002 No. 3, pp. 23-45.

Gyimah-Brempong, K. (2002), "Corruption, economic growth, and income inequality in Africa", Economics of Governance, Vol. 2002 No. 3, pp. 183-209. 
JES

47,6

Honohan, P. (2008), "Cross-country variation in household access to financial services", Journal of Banking and Finance, Vol. 32, pp. 2493-2500.

Kempson, E. and Whyley, C. (1999), Kept Out or Opted Out? Understanding and Combating Financial Exclusion, Policy Press, Bristol.

Kendall, J., Mylenko, N. and Ponce, A. (2010), "Measuring financial access around the world", World Bank Policy Research Working Paper Series, WPS 5253, World Bank Group, Washington, DC.

Lämmermann, S. (2010), Financial Exclusion and Access to Credit, Social Watch Thematic Reports, European Microfinance Network, Brussels, available at http://www.socialwatch.org/sites/ default/fiels/Eu_SW2010_Financial_eng.pdf (accessed June 2019).

Leyshon, A. and Thrift, N. (1995), "Geographies of financial exclusion: financial abandonment in Britain and the United States", Transactions of the British Institute of Geographers, New Series, Vol. 20, pp. 312-341.

LiTS (2010), Life in Transition Survey II (LiTS II), European Bank for Reconstruction and Development, London, and the World Bank Group, Washington, DC.

McKillop, D. and Wilson, J.O.S. (2007), "Financial exclusion", Public Money and Management, Vol. 27, pp. 9-12.

Mo, P.H. (2009), "Income distribution polarization and economic growth: channels and effects", Indian Economic Review, Vol. 44 No. 1, pp. 107-123.

Mohieldin, S.M. and Wright, W.P. (2000), "Formal and informal credit market in Egypt", Economic Development and Cultural Change, Vol. 48, pp. 657-670.

Nissan, E. and Naghshpour, S. (2013), "Connecting corruption to ethnic polarization and religious fractionalization”, Journal of Economic Studies, Vol. 40 No. 6, pp. 763-774.

Rajan, R.G. and Zingales, L. (2003), "The great reversals: the politics of financial development in the 20th century", Journal of Financial Economics, Vol. 69, pp. 5-50.

Rojas-Suarez, L. and Amado, M.A. (2014), "Understanding latin America's financial inclusion gap", Center for Global Development Working Paper, Vol. 367, Washington, DC.

Sen, A. (2006), "Conceptualizing and measuring poverty", in Grusky, D.B. and Kanbur, R. (Eds), Poverty and Inequality, Stanford University Press, Stanford, California.

Sinclair, S. (2001), Financial Exclusion: An Introductory Survey, Centre for Research into Socially Inclusive Services, Heriot Watt University, Edinburgh.

World Bank (2012), Global Financial Development Report 2013: Rethinking the Role of the State in Finance, World Bank Series, World Bank Group, Washington, DC.

You, J.-S. and Khagram, S. (2005), "A comparative study of inequality and corruption”, American Sociological Review, Vol. 70 No. 1, pp. 136-157.

\section{Further reading}

Miller, M., Reichelstein, J., Salas, C. and Zia, B. (2015), "Can you help someone become financially capable? A meta-analysis of the literature”, The World Bank Research Observer, Vol. 30 No. 2, pp. 220-246.

\section{Corresponding author}

Germana Corrado can be contacted at: corrado@uniroma2.it

For instructions on how to order reprints of this article, please visit our website:

www.emeraldgrouppublishing.com/licensing/reprints.htm

Or contact us for further details: permissions@emeraldinsight.com 